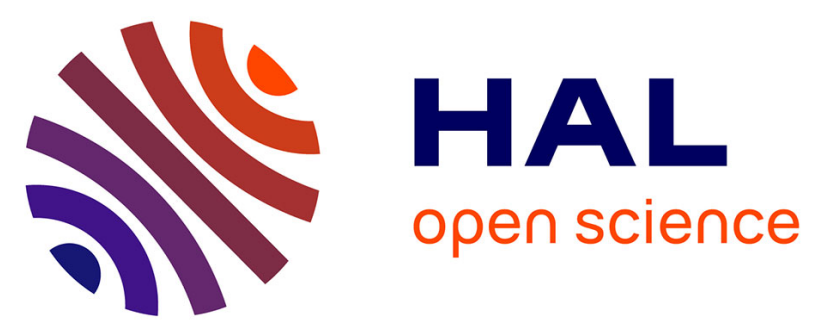

\title{
A Tertiary asthenospheric flow beneath the southern French Massif Central related to the west Mediterranean extension evidenced by upper mantle seismic anisotropy Guilhem Barruol, Michel Granet
}

\section{- To cite this version:}

Guilhem Barruol, Michel Granet. A Tertiary asthenospheric flow beneath the southern French Massif Central related to the west Mediterranean extension evidenced by upper mantle seismic anisotropy. Earth and Planetary Science Letters, 2002, 202 (1), pp.31-47. 10.1016/S0012-821X(02)00752-5 . insu-00150214

\section{HAL Id: insu-00150214 https://hal-insu.archives-ouvertes.fr/insu-00150214}

Submitted on 27 Oct 2016

HAL is a multi-disciplinary open access archive for the deposit and dissemination of scientific research documents, whether they are published or not. The documents may come from teaching and research institutions in France or abroad, or from public or private research centers.
L'archive ouverte pluridisciplinaire HAL, est destinée au dépôt et à la diffusion de documents scientifiques de niveau recherche, publiés ou non, émanant des établissements d'enseignement et de recherche français ou étrangers, des laboratoires publics ou privés. 


\title{
A Tertiary asthenospheric flow beneath the southern French Massif Central indicated by upper mantle seismic anisotropy and related to the west Mediterranean extension
}

\author{
Guilhem Barruol $^{\mathrm{a}, *}$, Michel Granet ${ }^{\mathrm{b}}$ \\ a Laboratoire de Tectonophysique, CNRS, Université Montpellier II, 34095 Montpellier, France \\ b Institut de Physique du Globe, 5 rue Descartes, 67084 Strasbourg, France
}

Received 12 February 2002; received in revised form 3 June 2002; accepted 4 June 2002

\begin{abstract}
Upper mantle flow beneath the French Massif Central is investigated using teleseismic shear wave splitting induced by seismic anisotropy. About 25 three-component stations (short period, intermediate and broadband) were installed during the period 1998-1999 in the southern Massif Central, from the Clermont Ferrand volcanic area to the Mediterranean Sea. Teleseismic shear waves (SKS, SKKS and PKS) were used to determine the splitting parameters: the fast polarization direction and the delay time. Delay times ranging between 0.7 and $1.5 \mathrm{~s}$ have been observed at most of the sites. The azimuths of the fast split shear waves trend homogeneously NW-SE in the southern Massif Central suggesting a homogeneous mantle flow beneath this area. The observed NW-SE direction differs from the $\mathrm{N} 100^{\circ} \mathrm{E}$ Pyrenean anisotropy further south. It does not appear to be correlated to Hercynian structures nor to the present-day motion of the plate but is well correlated to the Tertiary extension direction. We propose that the opening of the western Mediterranean induced by the rotation of the Corsica-Sardinia lithospheric block and the roll-back to the SE of the Tethys slab may have generated a large asthenospheric mantle flow beneath the southern Massif Central and a deflection of the up going plume centered beneath the northern Massif Central toward the SE. (C) 2002 Elsevier Science B.V. All rights reserved.
\end{abstract}

Keywords: S-waves; wave splitting; anisotropy; Central Massif; asthenosphere; Tertiary; extension

\section{Introduction}

The Massif Central (MC) in France is a portion of the Hercynian belt that has been uplifted dur-

\footnotetext{
* Corresponding author. Present address: Jeune équipe Terre-Océan, Université de Polynésie française, P.O. Box 6570, 98702 Faaa Aéroport, Tahiti, Polynésie française. Fax: +689-803-842.

E-mail address: barruol@upf.pf (G. Barruol).
}

ing Cenozoic times. It represents one of the largest volcanic provinces of western Europe whose geological evolution has been related with the Alpine orogeny [1] and the Cenozoic extensional regime. The MC has been affected, as the whole of western Europe, by the Oligocene extension, which induced a thinning of the crust beneath the Limagne graben [2]. The recent volcanism led to a shallowing of the lithosphereasthenosphere transition to depths of about $50 \mathrm{~km}[3]$. 
Although the volcanic activity in the MC began during Paleocene times on its periphery (Bourgogne, Causse, Bas Languedoc), the main volcanic activity occurred during Miocene and Pliocene times in the central part (Cantal, Mont Dore). The maximum geographical spreading of this volcanism occurred during the lower Pliocene (between 7 and $4 \mathrm{Ma}$ ) [4]. Some of the volcanoes were still active during Quaternary times (Vivarais, Languedoc and Chaîne des Puys, for instance) [5]. From late Miocene to present, an age progression has been described along three branches originating from the Cantal area where the oldest (between 14 and $10 \mathrm{Ma}$ ) volcanism is observed, whereas the most recent volcanism (younger than $1 \mathrm{Ma}$ ) is found in the Chaîne des Puys to the north, in the Languedoc area to the south, and in the Ardèche area to the southeast.

The anomalously high topography, the negative Bouguer anomaly [6], the high heat flow [7], the surface wave attenuation [8] and the low P-wave velocity anomaly $[9,10]$ are all compatible with the presence of hot material at upper mantle depths beneath the MC. Numerical models [3,11] suggest that the mantle temperature beneath the northern $\mathrm{MC}$ is $100-200^{\circ} \mathrm{C}$ higher than the surrounding mantle. Although the texture analyses of mantle xenoliths [12] suggested the presence of several small scale asthenospheric diapirs intruding the lithosphere, the size and extension of the mantle intrusion(s) are still debated.

In 1991-1992, seismic stations were deployed in the northern MC [9]. The resulting upper mantle seismic tomography evidenced a large, low velocity body beneath the Cantal and Velay areas, visible down to about $250 \mathrm{~km}$ [9], interpreted as a possible signature of the hot mantle plume from which the MC volcanism originated [13]. Interestingly, this tomographic image suggested that the low velocity anomaly could have some vertical and southward extent, but the design of this 1991-1992 experiment did not allow the characterization of the extension of this low velocity anomaly.

In order to enlarge this tomographic image at the scale of the whole MC, we conducted a temporary deployment of a seismic network in 19981999. We installed 25 three-component seismic stations on the southern part of the MC. Our aim was to extend the $3-\mathrm{D}$ velocity model not only deeper but also southward to the Mediterranean Sea and to make the connection with the Pyrenean tomographic model [14]. This deployment should help to constrain the deep structures of the mantle beneath the southern MC, to map the lateral variations of the lithospheric thickness, and to better constrain the lateral and vertical extent of the mantle plume. Mapping the upper mantle flow from seismic anisotropy and teleseismic shear wave splitting was another aim of this seismic study that we present in this paper.

For the last decade, seismic anisotropy has been used to study upper mantle tectonics $[15,16]$. Shear wave splitting is directly induced by seismic anisotropy: a polarized shear wave crossing an anisotropic medium is split into two perpendicularly polarized waves that propagate at different velocities. Two anisotropy parameters may be retrieved from three-component seismic records: the difference in arrival time $(\delta t)$ between the two split shear waves, which depends on the thickness and on the intrinsic anisotropy of the medium, and the orientation of the split waves' polarization planes (the azimuth $\phi$ for the fast wave), which is related to the orientation of the structure.

Seismic anisotropy in the upper mantle is broadly assumed to result from intrinsic elastic anisotropy of rock-forming minerals [17] and from their preferred orientations developed in response to tectonic flow. Olivine, which represents the main upper mantle constituent and which is the most anisotropic upper mantle mineral phase, controls upper mantle anisotropy $[18,19]$. Since shear wave splitting is a direct result of anisotropy, and hence of rock deformation, it is possible by measuring this splitting to investigate upper mantle structure in relation to plate tectonics. We present in this paper observations of splitting of teleseismic shear waves recorded on the southern flank of the MC. We also discuss the possible upper mantle fabric in light of the various tectonic events that could have played a role: the motion of the Eurasian plate, the Hercynian orogeny, the hotspot emplacement, and the Tertiary extension related to the opening of the western Mediterranean. 
Table 1

Station location and mean anisotropy parameters

\begin{tabular}{|c|c|c|c|c|c|c|c|c|}
\hline Station & $\begin{array}{l}\text { Latitude } \\
\left({ }^{\circ} \mathrm{N}\right)\end{array}$ & $\begin{array}{l}\text { Longitude } \\
\left({ }^{\circ} \mathrm{E}\right)\end{array}$ & $\begin{array}{l}\phi \\
\left(^{\circ}\right)\end{array}$ & $\begin{array}{l}\sigma \phi \\
\left(^{\circ}\right)\end{array}$ & $\begin{array}{l}\delta t \\
(\mathrm{~s})\end{array}$ & $\begin{array}{l}\sigma \delta t \\
\text { (s) }\end{array}$ & $\begin{array}{l}\text { Number of } \\
\text { measurements }\end{array}$ & Quality \\
\hline \multirow[t]{2}{*}{ ALB } & 43.895 & 2.456 & 88 & 16 & 1.45 & 0.02 & 2 & $g+f+p$ \\
\hline & & & - & - & - & - & 0 & $\mathrm{~g}$ \\
\hline \multirow[t]{2}{*}{ CLR } & 43.882 & 3.323 & 138 & 15 & 0.89 & 0.10 & 10 & $g+f+p$ \\
\hline & & & 130 & 14 & 0.96 & 0.09 & 8 & $\mathrm{~g}$ \\
\hline \multirow[t]{2}{*}{$\mathrm{CNG}$} & 44.400 & 3.226 & 137 & 5 & 1.03 & 0.19 & 3 & $g+f+p$ \\
\hline & & & 126 & 5 & 0.61 & 0.20 & 1 & $\mathrm{~g}$ \\
\hline \multirow[t]{2}{*}{$\mathrm{COU}$} & 43.479 & 2.723 & 141 & 13 & 0.95 & 0.25 & 6 & $g+f+p$ \\
\hline & & & 96 & 8 & 0.70 & 0.20 & 1 & $\mathrm{~g}$ \\
\hline \multirow[t]{2}{*}{ DIO } & 43.931 & 4.299 & 116 & 5 & 1.34 & 0.07 & 6 & $g+f+p$ \\
\hline & & & 116 & 6 & 1.36 & 0.04 & 2 & $\mathrm{~g}$ \\
\hline \multirow[t]{2}{*}{ ENS } & 43.310 & 3.110 & 111 & 5 & 0.96 & 0.18 & 2 & $g+f+p$ \\
\hline & & & 121 & 12 & 0.70 & 0.21 & 1 & $\mathrm{~g}$ \\
\hline \multirow[t]{2}{*}{ GUZ } & 43.741 & 3.935 & 106 & 5 & 1.16 & 0.16 & 4 & $g+f+p$ \\
\hline & & & 99 & 6 & 1.11 & 0.01 & 2 & g \\
\hline \multirow[t]{2}{*}{ LUC } & 44.656 & 3.890 & 74 & 24 & 1.54 & 0.16 & 5 & $g+f+p$ \\
\hline & & & - & - & - & - & 0 & g \\
\hline \multirow[t]{2}{*}{ MIR } & 44.144 & 2.172 & 129 & 9 & 1.22 & 0.09 & 5 & $g+f+p$ \\
\hline & & & 124 & 5 & 1.03 & 0.26 & 2 & g \\
\hline \multirow[t]{2}{*}{ MMJ } & 43.706 & 4.664 & 110 & 4 & 0.70 & 0.04 & 6 & $g+f+p$ \\
\hline & & & 95 & 12 & 0.64 & 0.22 & 1 & $\mathrm{~g}$ \\
\hline \multirow[t]{2}{*}{ PDS } & 44.322 & 2.724 & 131 & 3 & 1.02 & 0.08 & 11 & $g+f+p$ \\
\hline & & & 134 & 4 & 0.95 & 0.03 & 6 & $\mathrm{~g}$ \\
\hline \multirow[t]{2}{*}{ RAB } & 43.830 & 1.716 & 82 & 40 & 0.78 & 0.21 & 4 & $g+f+p$ \\
\hline & & & - & - & - & - & 0 & $\mathrm{~g}$ \\
\hline \multirow[t]{2}{*}{ RMZ } & 44.400 & 4.496 & 121 & 9 & 0.72 & 0.16 & 5 & $g+f+p$ \\
\hline & & & 101 & 7 & 0.60 & 0.14 & 2 & g \\
\hline \multirow[t]{2}{*}{ SAI } & 43.362 & 2.172 & 16 & 14 & 1.26 & 0.23 & 6 & $g+f+p$ \\
\hline & & & 52 & 15 & 0.79 & 0.27 & 2 & g \\
\hline \multirow[t]{2}{*}{ BOPU } & 42.870 & 2.876 & 112 & 5 & 1.58 & 0.11 & 8 & $g+f+p$ \\
\hline & & & 116 & 6 & 1.43 & 0.10 & 4 & $\mathrm{~g}$ \\
\hline \multirow[t]{2}{*}{ BLRC } & 44.286 & 3.767 & 133 & 6 & 0.78 & 0.14 & 6 & $g+f+p$ \\
\hline & & & 125 & 7 & 0.61 & 0.11 & 4 & $\mathrm{~g}$ \\
\hline \multirow[t]{2}{*}{$\mathrm{CFF}$} & 45.762 & 3.102 & 142 & 6 & 1.79 & 0.70 & 1 & $g+f+p$ \\
\hline & & & - & - & - & - & 0 & g \\
\hline \multirow[t]{2}{*}{ St08 } & 45.359 & 2.801 & 122 & 10 & 0.90 & 0.20 & 1 & $g+f+p$ \\
\hline & & & 122 & 10 & 0.90 & 0.20 & 1 & $\mathrm{~g}$ \\
\hline \multirow[t]{2}{*}{ St09 } & 44.860 & 3.833 & 145 & 4 & 1.15 & 0.12 & 1 & $g+f+p$ \\
\hline & & & 145 & 4 & 1.15 & 0.12 & 1 & $\mathrm{~g}$ \\
\hline \multirow[t]{2}{*}{ St11 } & 44.781 & 2.126 & 116 & 16 & 1.10 & 0.40 & 1 & $g+f+p$ \\
\hline & & & 116 & 16 & 1.10 & 0.40 & 1 & $\mathrm{~g}$ \\
\hline \multirow[t]{2}{*}{ ARBF } & 43.492 & 5.333 & 94 & 7 & 1.29 & 0.15 & 4 & $\mathrm{~g}$ \\
\hline & & & 95 & 7 & 1.31 & 0.12 & 6 & $g+f+p$ \\
\hline
\end{tabular}

Station location and mean splitting parameters calculated with all the results $(\mathrm{g}+\mathrm{f}+\mathrm{p})$ or with the only good measurements $(\mathrm{g})$. The number and quality of individual splitting measurements from which the average values are calculated is tabulated.

\section{Data and results}

Teleseismic events were recorded by three-component seismic stations mainly from the French
LITHOSCOPE network. The main station deployment occurred between October 1998 and August 1999. Table 1 lists the station locations presented in Fig. 1. We began the experiment 


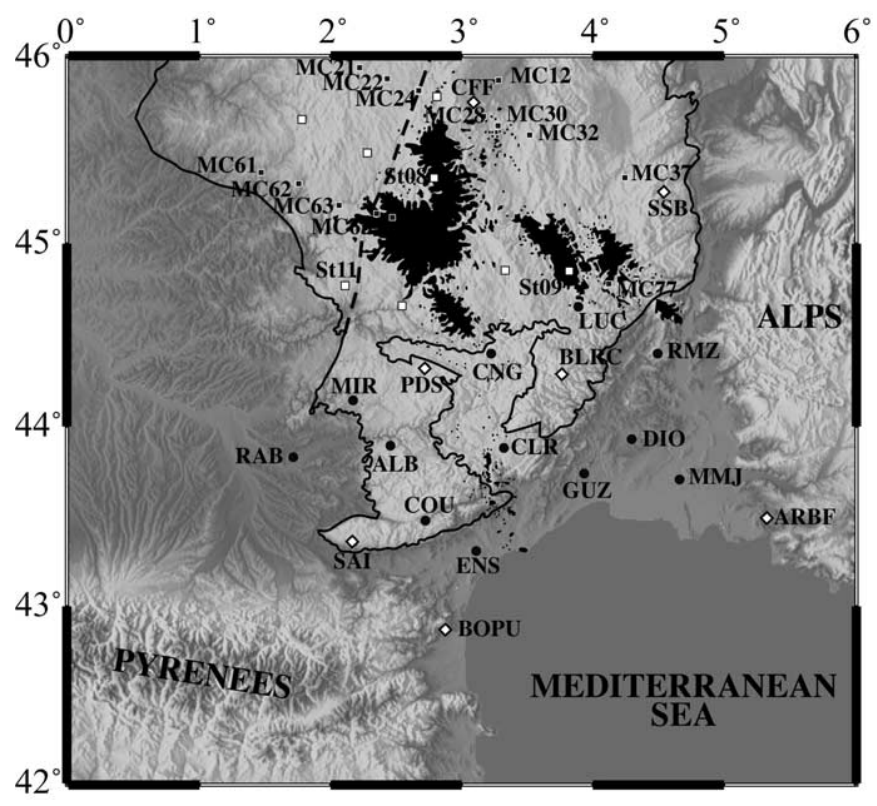

Fig. 1. Map of the station locations. The continuous line represents the contour of the Hercynian basement and the dashed line the 'Sillon Houiller'. The Cenozoic volcanic fields are in black. The black squares (station MC) indicate stations with splitting measurements $[25,27]$. White squares represent short period (1 s) three-component stations from the GFZ Potsdam. Due to the short time of installation, anisotropy measurements were only possible at stations St08, St09 and St11. CFF and ARBF are ReNaSS broadband stations. SSB is a geoscope station. The black circles represent short, then intermediate period (1, then $5 \mathrm{~s}$, respectively) three-component stations, whereas diamonds represent broadband stations.

for three months with short period (1 s) sensors recording at 31.25 samples per second. We replaced these sensors in January 1999 by intermediate period sensors (5 s Lennartz) that recorded at the same rate up to August 1999. Two broadband stations from the French 'Réseau Large Bande Mobile' equipped with Streickeisen STS-2 seismometers were installed in May 1999 and remained in the field at PDS and SAI up to January 2000. Two other broadband stations from Leeds University (Mars88 equipped with Guralp CMG3) ran from October 1998 to August 2000 at BLRC and BOPU. Continuous recording allowed us to select and extract teleseismic events at convenient distances and magnitudes suitable for SKS, SKKS and PKS splitting measurements. In order to avoid noise contamination of the splitting measurements, we kept only events characterized by signal to noise ratio of the SKS phase higher than 2. From the whole data set of teleseismic events located at a distance greater than $85^{\circ}$ and of magnitude greater than 5.8, about 60 events were suitable for shear wave splitting measurements (Background Data Set ${ }^{1}$, Table 2). Of these events, less than 20 were recorded during the main experiment (January-August 1999). The event origins and locations (Background Data Set ${ }^{1}$, Table 2) are taken from the US Geological Survey (USGS) Preliminary Determination of Epicenters, and the phase arrivals were computed using the IASP91 Earth reference model [20].

Most individual splitting measurements (Background Data Set $^{1}$, Table 3) were performed on earthquakes occurring at distances in the range $85-120^{\circ}$. We measured the shear wave splitting using the Silver and Chan [21] algorithm. This method determines the anisotropy parameters, $\phi$ and $\delta$, that best minimizes energy on the transverse component of the seismogram for a selected time window. For each, we report the split phase

\footnotetext{
1 http://www.elsevier.com/locate.epsl
} 
on which we performed the measurement, the splitting parameters $(\phi, \delta t)$ with their $1 \sigma$ uncertainty, determined from the $95 \%$ confidence interval in the $(\phi-\delta t)$ domain, and the backazimuth of the event. We ascribe a quality factor (good, fair, or poor) to the measurements, depending on the signal to noise ratio of the initial phase, the rectilinear polarization of the particle motion in the horizontal plane after anisotropy correction, and the waveform correlation between the fast and slow split shear waves. We present in Fig. 2 three examples of splitting measurements recorded by short (CLR), intermediate (GUZ) and broadband (PDS) sensors. We generally used the SKS phase, but for some events, we used the whole SKS+SKKS-wave train. For a few events occurring at epicentral distances between 130 and $140^{\circ}$, we successfully measured the splitting of PKS phases. We also deduced direct S-wave splitting for two events: for S-wave from event 99098 occurring at an epicentral distance of $80^{\circ}$, we considered this event deep enough $(562 \mathrm{~km})$ to assume that no splitting occurred on the source side of the seismic path. The result obtained from this $\mathrm{S}$ phase is fully consistent with the anisotropy parameters deduced from SKS splitting measurements. We also used event 99028 occurring at a depth of $66 \mathrm{~km}$ and at an epicentral distance of about $83^{\circ}$. The measurements were

Fig. 2. Examples of splitting measurements at three stations equipped with different sensors: SKKS phase for event 98271 at CLR, with a short period (1 s) sensor, SKS phase for event 99024 at GUZ with an intermediate period sensor (5 s), SKS phase for event 99315 at PDS with a broadband sensor. For each station we show two upper traces: the initial radial (a) and transverse (b) components (energy on the transverse component). Two lower traces (c and d): the radial and transverse traces corrected for anisotropy (there is no longer energy on the transverse component). The shaded area gives the time window on which the splitting measurement is done and the dashed lines represent the predicted phase arrival times (IASP91 model). The four diagrams on the right plot the fast and slow split shear waves (continuous and dashed line, respectively) raw (e) and corrected (f) for the best-calculated delay time. Particle motions in the horizontal plane are shown below, also uncorrected (g) and corrected $(\mathrm{h})$ for the anisotropy: the elliptical particle motion becomes rectilinear when the anisotropy is corrected. made on the whole S+SKS-wave train, the two phases arriving almost simultaneously at this distance. Although the S and SKS rays do not sample exactly the same mantle (they are $24 \mathrm{~km}$ apart at $150 \mathrm{~km}$ depth), the quality of the measurements at the southern stations and their similarity to the SKS splitting parameters led us to consider that this particular splitting measurement should primarily reflect the anisotropy beneath the station

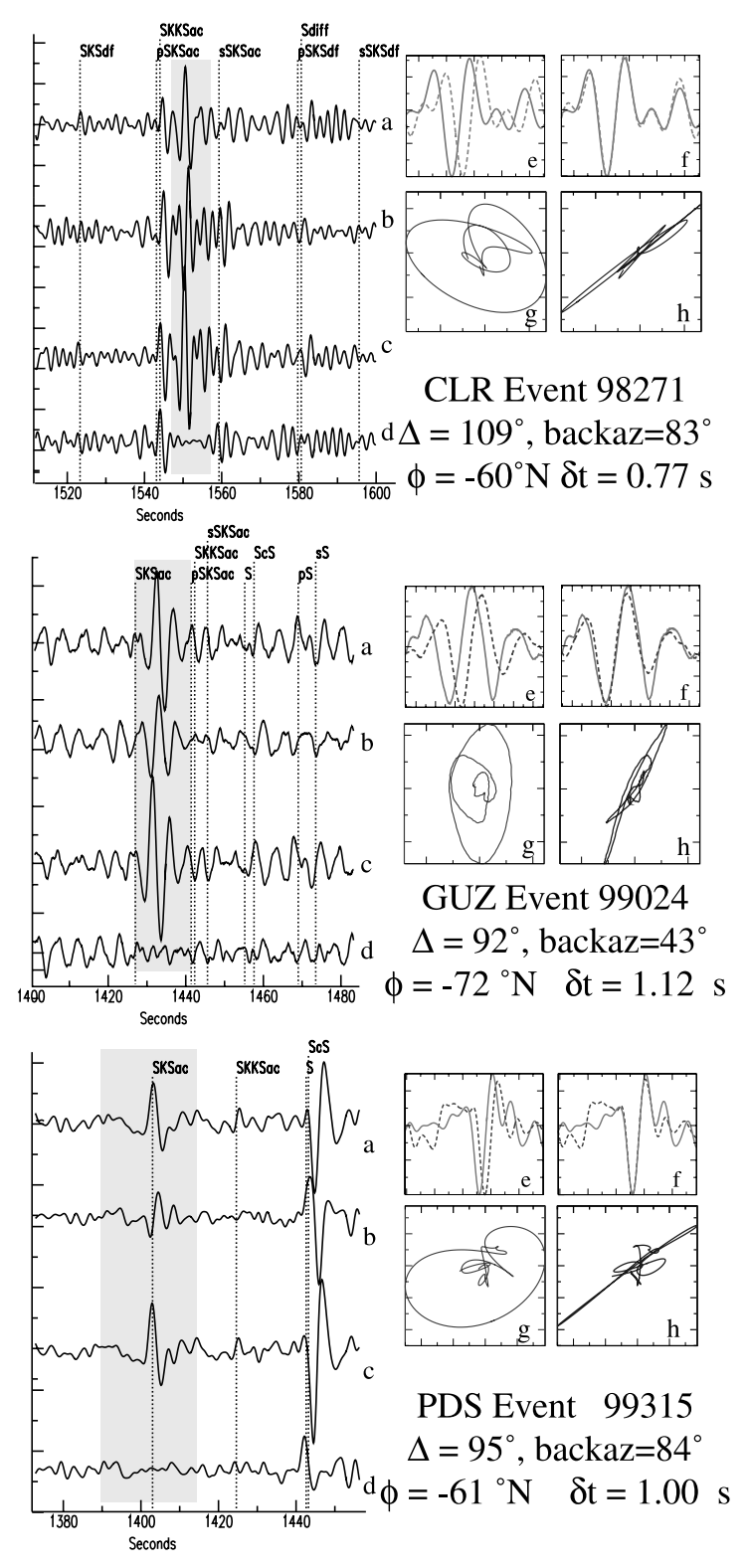




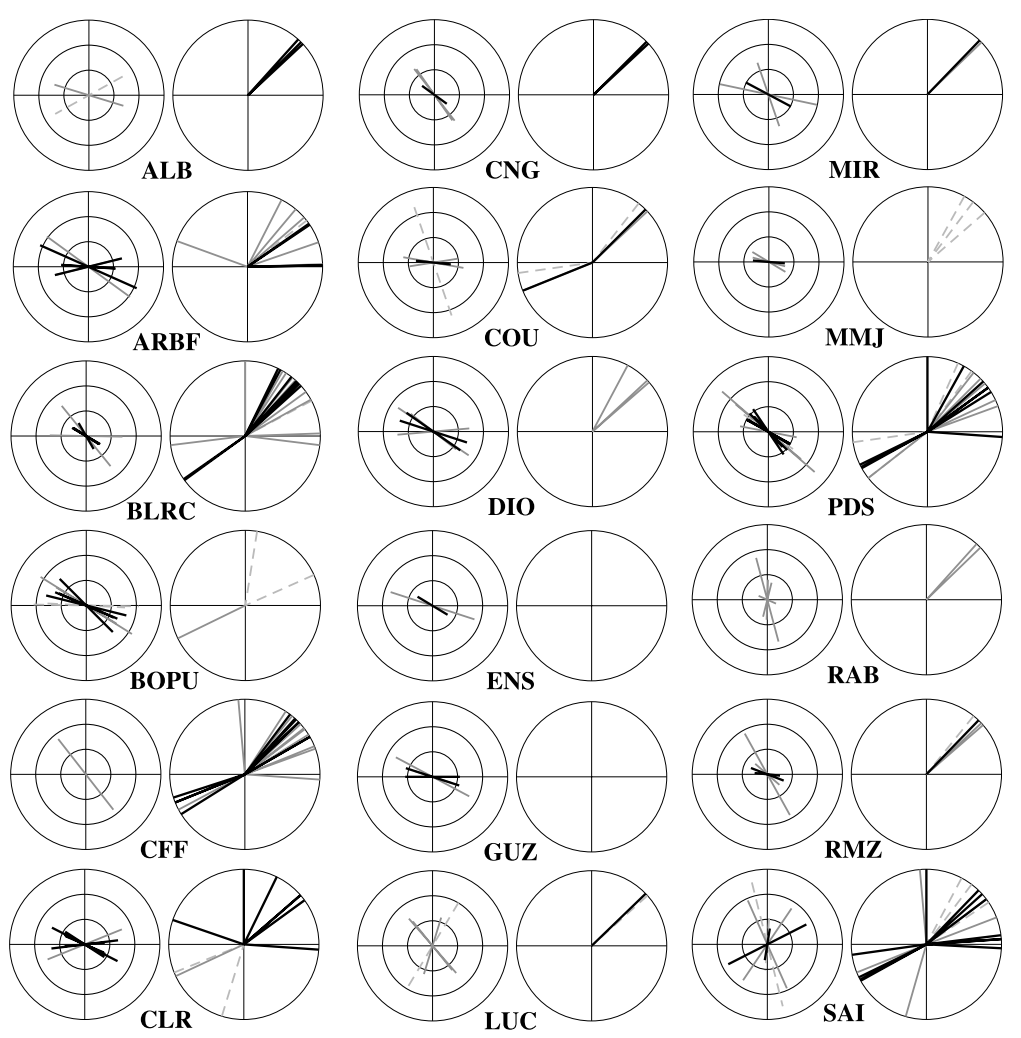

Fig. 3. For each station are presented the splitting (left) and the backazimuth for which no splitting is observed (right). For the splitting measurements, the trend of each segment represents the azimuth $\phi$ of the fast split shear wave and its length is proportional to the delay time $\delta t$ (up to $3.0 \mathrm{~s}$ ). Black lines correspond to well-constrained results, dark gray lines to fair and dashed lines to poorly constrained results (Background Data Set $^{1}$, Table A3).

and not a source side anisotropy. This S+SKS splitting measurement was the only one done at three stations from the northern group (St08, St09 and St11, reported in Table 1) that were running for a short time. We considered that the quality of these data is good enough to keep measurement and to have some confidence in the results, but they are only weakly representative of the region and we shall not discuss the results together with the southern stations.

The individual results of shear wave splitting are plotted in Fig. 3 in polar diagrams. The azimuths of the fast split shear wave together with the delay time is plotted on the left panel of such pairs of figures, whereas the backazimuths for which no splitting were detected are plotted on the right. These are called 'null' measurements and indicate either that there is no anisotropy beneath the station or that the initial polarization direction of the SKS-wave is parallel to the fast or slow direction in the anisotropic layer. Black lines represent the best-constrained results whereas the gray lines represent measurements of lower quality. Good splitting measurements were observed at almost all sites except four. For three of them (ALB, LUC and RAB), this is likely related to a

Fig. 4. Map of the SKS splitting measurements at the surface (a), and projected along the rays at $100 \mathrm{~km}$ (b) and at $200 \mathrm{~km}$ depths (c). As in Fig. 3, the black measurements are the best constrained, and the gray measurements represent measurements of lower quality. 

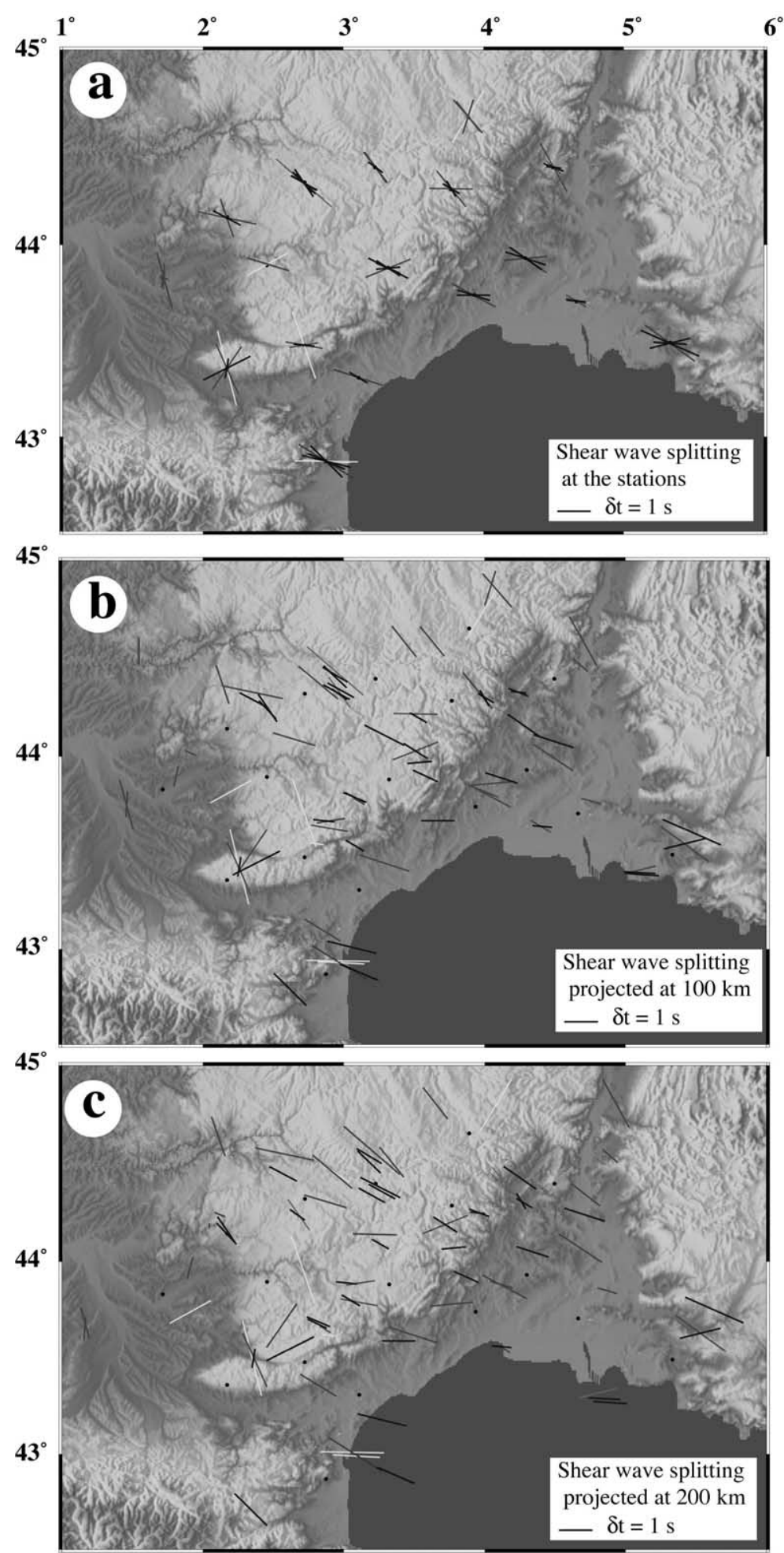
lack of data, since very few nulls are observed during the same period. On the other hand, for the permanent station CFF at Clermont Ferrand, the absence of splitting observation could be related to the absence of anisotropy along the vertical direction beneath the station, since numerous nulls of good quality are observed. From systematic analyses of more than 10 years of data at the geoscope station SSB further east, Barruol and Hoffmann [22] observed only two positive splitting results (arriving at the same backazimuth) and a large number of nulls, suggesting a mostly isotropic structure beneath the station. This apparent isotropy along the vertical direction may result either from vertically oriented olivine aaxis, or from large scale heterogeneities, or from the presence of two anisotropic layers with perpendicularly oriented fast axes or simply from absence of deformation of the medium [22]. As shown below, measurements of olivine and orthopyroxene crystal lattice preferred orientation of peridotite nodules sampled in the northern MC [23] do not favor this last hypothesis.

SKS splitting has a poor vertical resolution because the splitting of a teleseismic shear wave observed at the Earth's surface may be acquired anywhere along the ray between the station and the core-mantle boundary. It is, however, broadly accepted from seismological and petrophysical arguments that most of the anisotropy lies within the uppermost $400 \mathrm{~km}$ of the Earth. There are some qualitative arguments that can help to vertically locate the anisotropy within the uppermost mantle. At a given site, for instance, homogeneous anisotropy parameters deduced from events with different backazimuths strongly favor superficial and homogeneous mantle deformation. We observe such homogeneity at the central stations and this could suggest a shallow (i.e., above $200 \mathrm{~km}$ ) anisotropy. The lithosphere is relatively thin beneath the northern MC $(<60 \mathrm{~km})$, and probably less than $80 \mathrm{~km}$ thick beneath the southern MC, so part of the recorded anisotropy may therefore lie within the asthenospheric upper mantle. Alternatively, the scattering of the anisotropy parameters observed at few southwestern stations (particularly at RAB and SAI) suggests either some superficial (i.e., $<100 \mathrm{~km}$ deep) heteroge- neous structure beneath the station (lateral variations, for instance) or the presence of several layers of anisotropy that may induce some backazimuthal variations in the anisotropy parameters [24].

In order to test the extent of the upper mantle deformation, i.e., the large scale stability of the anisotropy parameters, and whether scattering at a given station reflects lateral structure variation or more complex structures such as the presence of several anisotropic layers, we present in Fig. 4 anisotropy maps on which each individual splitting measurement is projected at a given depth along the incoming ray. This representation is both helpful, since it plots the splitting parameters at the place where it could have been partially acquired, but also imperfect because it plots a final, integrated splitting at a depth where splitting was perhaps not fully completed. The individual splitting measurements (Background Data Set $^{1}$, Table 3 ) are projected at the surface (Fig. 4a), at 100 (Fig. 4b) and $200 \mathrm{~km}$ depth (Fig. 4c). These maps first show that the lateral mantle sampling is homogeneous despite the relatively sparse network density (about $50 \mathrm{~km}$ between stations) and the sparse backazimuthal coverage. Events mainly arrived from the NE and the SW. Second, except for some lower quality events, the homogeneous NW-SE trend in the central part of the network is particularly striking in the 100 and $200 \mathrm{~km}$ depth maps and suggests a uniform and pervasive structure beneath this area. This 'channel' structure appears to be at least $400 \mathrm{~km}$ long (and in fact much longer when incorporating the individual measurements made at the northern stations St08, St09 and St11 and the reprocessed data at the northern MC stations [25]) and about $200 \mathrm{~km}$ wide. Third, the scattering observed at SAI and RAB appears from these projections to be compatible with variations in the lateral structure at mantle depth. At SAI, for instance, the three measurements with roughly $\mathrm{N}-\mathrm{S}$ trending $\phi$ (events 99095, 99130 and 99323) sample the same upper mantle, whereas the two NE-SW trending $\phi$ (events 99024 and 99345) sample a mantle area slightly offset to the NE. At RAB, the absence of good measurements weakens the conclusions, but the two $\mathrm{N}-\mathrm{S} \phi$ measurements 
(events 99093 and 98281) sample mantle anisotropy SW from the station, whereas the $\mathrm{N} 110^{\circ} \mathrm{E}$ trending $\phi$ (event 99098) integrates anisotropy NE from the station. Although the small number of splitting measurements at these sites does not allow to test the presence of several anisotropic layers, the results from these southwestern stations are compatible with lateral heterogeneities in the upper mantle.

Despite the small data set related to the short interval of the network deployment, the overall coherency of the results at most stations allows us to calculate the mean splitting parameters at each site. We used the averaging method presented by Silver and Chan [21] that weights each individual measurement by its $95 \%$ confidence interval (reported in Background Data Set $^{1}$, Table 3), so that poorly constrained results have a smaller contribution to the mean result than the best-constrained measurements. To check the consistency of the results, we determined the mean splitting parameters $(\phi, \delta t)$ using two sets of data: (1) the whole set of non null measurements, and (2) the good non null measurements only (Table 1). A first group of four stations (CFF, ALB, LUC, RAB), devoid of good splitting measurements, does not allow further discussion of the difference between the mean anisotropy determined from the two sets of data. For a second group of stations (i.e., PDS, CLR, CNG, DIO, ENS, GUZ, BOPU, BLRC, MIR, ARBF), the mean azimuth $\phi$ (ranging between $\mathrm{N} 094^{\circ}$ at $\mathrm{ARBF}$ and $\mathrm{N} 138^{\circ}$ at CLR) obtained from the two different data sets are consistent within $\pm 10^{\circ}$. Such a coherency is primarily observed in a NW-SE trending corridor. However, mean delay times at some sites may display variations larger than $0.2 \mathrm{~s}$, depending on the quality of the data taken into account. This occurs particularly at stations where very few good measurements are observed (e.g., CNG, MIR, ENS). The third group of stations shows larger differences $\left(>10^{\circ}\right.$ in $\phi$ and $>0.1 \mathrm{~s}$ in $\left.\delta t\right)$ in both anisotropy parameters deduced from the two data sets. This reflects a stronger scattering in the splitting observations. These stations are located on the southwestern (e.g., SAI, COU, RAB) and

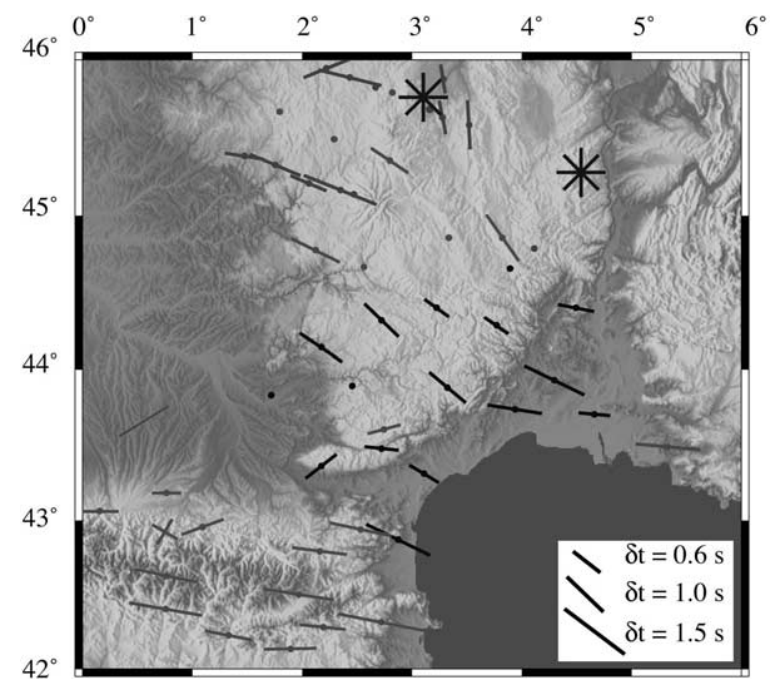

Fig. 5. Map of the mean splitting parameters calculated from the good measurements at each station from the southern MC and the Pyrenees [26]. There is no result at some sites (RAB, ALB, LUC), since they are devoid of good SKS splitting measurements. Also plotted are the good quality splitting measurements in the northern MC [25]. The stars indicate the absence of anisotropy observed at SSB [22] and CFF.

northeastern part of the network (e.g., RMZ, LUC).

In the central area of our network, the mean azimuth $\phi$ of the fast split shear wave is homogeneously aligned along a NW-SE trending corridor (Fig. 5). More precisely, $\phi$ trends NW-SE in the northwestern part of the network and rotates slightly to almost $\mathrm{E}-\mathrm{W}$ in the southeastern part of the network. Along this corridor, the mean $\delta t$ deduced from the good splitting observations (Table 1) are not characterized by such smooth variations as the azimuths' $\phi$ : the northern stations (PDS, CNG, CLR and BLRC) display small $\delta t$ (in the range $0.61-0.95 \mathrm{~s}$ ), whereas southern stations (GUZ, DIO and ARBF) display much higher $\delta t$ (in the range 1.11-1.36 s). MMJ, in the Rhône valley, has much lower $\delta t(0.64 \mathrm{~s})$ than surrounding stations. The southernmost station BOPU $\left(\phi=\mathrm{N} 116^{\circ} \mathrm{E}, \delta t=1.43\right)$ is characterized by similar parameters to those observed in the Pyrenees [26]: a high $\delta t$ and $\phi$ trending roughly parallel to the Pyrenean belt. 


\section{Discussion: the origin of the anisotropy}

In order to discuss the nature of the mantle deformation from which the observed splitting originated, we present in Fig. 5 our measurements together with anisotropy measurements from two other studies performed in the northern MC [25] and in the Pyrenees [26].

From data recorded by a few three-component stations that were running during the 1991-1992 seismic experiment, some anisotropy measurements were performed by Granet et al. [27] and more recently reprocessed by Babuska et al. [25]. Although the results are deduced from a single event, one of the major findings of this study is a strong variation in the anisotropy parameters obtained at stations located on both sides of the $\mathrm{N}-\mathrm{S}$ trending 'Sillon Houiller', which was an active fault during the Variscan orogeny. Stations on the western side of the fault are characterized by $\phi$ trending $\mathrm{N} 100^{\circ} \mathrm{E}$, whereas stations lying on its eastern side are characterized by $\phi$ trending roughly $\mathrm{N}-\mathrm{S}$. These observations led the authors to conclude that the anisotropy beneath the northern MC is most likely located in the uppermost mantle and that the 'Sillon Houiller' could represent a major lithospheric boundary.

Further south in the Pyrenees, seismic anisotropy measurements [26] displayed a homogeneous pattern characterized by relatively strong delay times (generally above 1.0 and often above $1.3 \mathrm{~s}$ ) and $\phi$ trending parallel to the belt (i.e., $\mathrm{N} 100^{\circ} \mathrm{E}$ ). The small scale delay time variations observed in the central part of the belt [28], but also the correlation of $\phi$ with the Hercynian and Pyrenean tectonic structures [26], favor an anisotropy located primarily within the lithosphere. Geological and geophysical arguments also suggest that the resulting mantle deformation could reflect Pyrenean structures in the internal part of the belt but Hercynian structures beneath its external parts.

Our new measurements from the southern MC appear to be statistically different from those obtained in the Pyrenees: the azimuths' $\phi$ are oriented more NW-SE rather than $\mathrm{N} 100^{\circ} \mathrm{E}$ in the Pyrenees and the $\delta t$ s are statistically lower than $1.0 \mathrm{~s}$, particularly for the northern stations. We now draw inferences about the source regions of anisotropy and the processes that generate mantle deformation fabrics through a comparison of anisotropy signatures expected from these processes and observed splitting parameters.

\subsection{Plate motion-related asthenospheric flow}

At the scale of southern France, seismic anisotropy is characterized by distinct patterns (Pyrenees, northern MC, southern MC), suggesting either different sources of anisotropy and/or different tectonic processes or histories. Small scale variations in the anisotropy parameters are found in each pattern, suggesting a near surface origin of anisotropy. Although it is not possible to totally reject such a hypothesis, our observations are hardly compatible with an anisotropy primarily induced by an asthenospheric flow related to the present-day plate motion. The hypothesis explains neither the general trend of $\phi$, which is expected to trend NE-SW for Eurasia [29], nor the short scale variation in anisotropy parameters across lithospheric boundaries (across the North Pyrenean Fault or the 'Sillon Houiller'), nor the strong variations between the large $\delta t$ observed in the Pyrenees and the smaller $\delta t$ in the northern MC.

\subsection{Hercynian, lithospheric fabric}

The Hercynian belt outcropping in the southern MC is made of metamorphic terranes intruded by granitic bodies. This area is composed of crustal scale, south verging nappes, described by Matte [30] as the southern external domains of the belt. Although the surface geology at the scale of the southern MC displays strong heterogeneities both from composition (gneiss, schists, granites, ...) and from the trend of the various units, the azimuths of the nappes' displacement trend roughly from $\mathrm{N} 180^{\circ}$ to $\mathrm{N} 200^{\circ} \mathrm{E}$ [30]. One could argue that this structural pattern outcropping in the Hercynian crustal basement could be related to a uniform and pervasive upper mantle fabric. We wish to show, however, that there are strong arguments against this assumption.

First, the Hercynian basement is hidden in many places by Mesozoic or Cenozoic sedimenta- 
ry covers. More than half of our stations were not directly installed on Hercynian basement but, instead, on more recent sedimentary covers (Fig. 1), particularly beneath the southeastern part of our network. Analyzing geometrical relationships between Hercynian structures and the observed anisotropy in this part of our network is therefore impossible.

Second, there is no consensus on the expected upper mantle flow in such nappe tectonic context. Silver $[15,31]$ proposed that during a lithospheric collision, olivine a-axes could orient normal to the maximum compressive direction. The resulting fast anisotropy axis should be oriented normal to the convergence direction, i.e., roughly $\mathrm{NW}_{-}$ SE to E-W [30], which could be consistent with our observed $\phi$ pattern. On the other hand, one could consider that olivine a-axes should orient parallel to the shear direction and hence parallel to the convergence direction. In this context, olivine a-axes should be therefore oriented roughly $\mathrm{N}-\mathrm{S}$ to NE, i.e., without any relationship to our observations. Comparing our observations to tectonic predictions is hence highly speculative.

Third, in nappe tectonic contexts, one can expect large offsets between an outcropping crustal deformation and, if existing, the related mantle deformation at depth. This offset depends on the crustal thickness and on the dip of the crustal deformation zone. Although the exact geometry of the MC sutures in the lower crust and upper mantle remains speculative, a $30^{\circ}$ angle as presented by Matte [30] on MC crustal scale crosssection would mean that the outcropping Hercynian deformation at a given site could be related to a mantle deformation located $50-100 \mathrm{~km}$ further north (assuming crustal and lithospheric thicknesses of 30 and $60 \mathrm{~km}$ ). This prevents any relationship between outcropping geological structures and seismic anisotropy.

Fourth, the Tertiary thermal events (the plume emplacement and the rifting of the Gulf of Lion) may have mechanically and thermally thinned the preexisting lithosphere and, therefore, part of the Hercynian fabric may have been erased.

In summary, the discussion of the upper mantle Hercynian fabric beneath the southern MC is highly speculative. The lack of evidence favoring a clear Hercynian signature in the recorded anisotropy does not mean that there is no Hercynian anisotropy, but that predicting an anisotropy pattern at upper mantle depth from the outcropping Hercynian geology is hazardous.

\subsection{Plume passive spreading asthenospheric flow}

Upper mantle seismic velocity anomalies associated with a hot spot are rather well imaged [32]. Nevertheless, the associated upper mantle flow patterns and related anisotropy patterns are poorly known. Splitting measurements performed at oceanic stations located on hotspot-related volcanoes yield at most sites an absence of detectable anisotropy [22,23] or, at other sites, fast split shear waves polarized parallel to the absolute plate motion $[22,33]$. In all these studies, the restriction to a single station did not allow the geometry of the mantle flow pattern, relative to the plume interaction with the asthenosphere-lithosphere system, to be tested. The seismic network deployed in Iceland could have allowed this, but SKS splitting measurements [34] display a complex pattern that could result from the interaction between the Iceland plume and the mid-Atlantic ridge. More recently, ocean bottom seismometers were deployed around Hawaii to test such plume effect on the upper mantle flow [35]. Despite a small number of splitting measurements, the authors proposed that the anisotropy pattern is consistent with a superposition of a radial pattern, the expected plume effect [36], and a linear pattern induced by the plate motion, generating a 'parabolic asthenospheric flow'.

In the case of the MC, and assuming a flat lithosphere-asthenosphere boundary, the expected flow pattern related to the only plume should be primarily radial since the plate velocity is extremely low, of the order of few mm/yr [29]. However, this assumption is likely incorrect: the presence of various lithospheric blocks in the Hercynian belt [37] but also the presence of the neighboring Alpine and Pyrenean roots show that the bottom of the lithosphere is not flat at the regional scale and therefore that the plume-related asthenospheric flow could be strongly controlled by such topography. The absence of seismic ani- 
sotropy at some northern MC stations (CFF, for instance), together with the small delay times observed in the northern MC, could indicate either steeply dipping mantle lineations [36] or upper mantle structures perturbated at the vertical of the plume upwelling. Our NW-SE trending anisotropy in the southern MC could be also consistent with a radial flow pattern around the plume center, but we explain below that the plume upwelling has likely been deflected toward the SE by the Tertiary extensive episode that affected the Gulf of Lion.

\subsection{Tertiary, extension-related, asthenospheric flow}

At the end of Eocene times (Priabonian) and in the early Oligocene (Rupelian), western Europe suffered an extensive episode that generated the so-called European Cenozoic rift system (ECRIS), trending $\mathrm{N}-\mathrm{S}$ and marked by the Rhine graben, the Bresse and Limagne graben, the Ales basin in Languedoc and the Valencia trough in NE Spain. The extension direction of this Oligocene episode is about $\mathrm{E}-\mathrm{W}$ in France. Its origin remains debated but could be influenced by a lithosphere buckling generated by the Alpine tectonic [38].

In Languedoc and SE France, the extension continued during the late Oligocene and the whole Miocene. From sedimentological analyses, Séranne et al. [39] showed that this extensional event around the Gulf of Lion is tectonically distinct from the ECRIS event. The corresponding extension directions are orientated NW-SE in the southern MC [39]. This regional extension is interpreted as back-arc spreading episodes, induced by the roll-back of the Tethys slab subducting at that time toward the northwest beneath the Corsica-Sardinia lithospheric block. We wish to show that this slab retreat may have induced a NW-SE regional asthenospheric flow that may be preserved since that time and that could dominate the present-day observed anisotropy. We present a summarized chronology of the events occurring in this area taken from Séranne et al. [39] and Faccenna et al. [40].

From 80 to $30 \mathrm{Ma}$, the general tectonic regime of the western Mediterranean is dominated by the northward motion of Africa inducing the closure of the Tethys ocean through the subduction of its oceanic part beneath the Eurasian active margin. At Oligocene times, the collision of the Adriatic promontory with Eurasia induced important changes in the geodynamic evolution of the western Mediterranean that can be described as a succession of two rifting events followed by the creation of two oceanic basins. (i) From 30 to $22 \mathrm{Ma}$ occurred the rifting of the Gulf of Lion, i.e., the extension of the lithosphere located between the Languedoc and the Corsica-Sardinia block in its pre-rotation situation. This NW-SE extension is attributed to the early stage of the slab roll-back. (ii) It was followed between 22 and $17 \mathrm{Ma}$ by the drifting of the Corsica-Sardinia lithospheric block. This rotation induced by the sinking of the slab in the upper mantle is accompanied by the creation of new oceanic lithosphere in the Liguro-Provençal basin. (iii) From 17 to $10 \mathrm{Ma}$ occurred the rifting of the Corsica-Sardinia lithospheric block. (iv) This rifting is followed from $10 \mathrm{Ma}$ to present by the escape of the Calabrian block, and the creation of the oceanic Tyrrhenian basin induced by the second episode of slab sinking. (v) In the present-day situation, the subduction of the African oceanic lithosphere is located beneath Calabria. The slab itself is well imaged in the tomographic model, down to $600 \mathrm{~km}$ depth [41]. It appears to lie horizontally in the transition zone beneath Sardinia [42], suggesting its inability to fall into the lower mantle.

In this general context, we propose that the episode of broad lithospheric extension that created the Gulf of Lion, and particularly, the following stage of slab sinking southeast from the Corsica-Sardinia block and the related opening of the Liguro-Provençal oceanic basin may have induced a pressure gradient within the asthenosphere. This may have moved to the SE the low viscosity plume that was upwelling beneath the northern MC. The plume could have been deflected toward the SE and therefore, the upper mantle beneath the southern MC may have been affected by a regional scale asthenospheric flow. Furthermore, the lithosphere beneath the southern MC may have suffered a mechanical and thermal thinning. To illustrate this, we present in 
Fig. 6 some schematic NW-SE cross-section between the $\mathrm{MC}$ and the present-day Calabria, at the upper mantle scale.

The West European rifting ends $30 \mathrm{Myr}$ ago (Fig. 6a). At that time the rifting of the Gulf of Lion begins, induced by the first sinking of the Tethys slab beneath the Corsica-Sardinia block. This rifting is followed between 22 and $17 \mathrm{Ma}$ (Fig. 6b) by the rotation of this lithospheric block and the creation of the Liguro-Provençal oceanic lithosphere. This rotation ends at $17 \mathrm{Ma}$ and is followed by the break-up of the Sardinia block (Fig. 6c). A regional mantle flow is needed during this period in order to fill the space left behind the sinking slab. We propose that the slab retreat to the SE may have pulled the mantle from the NW. The presence beneath the MC of a hot, low viscous mantle material could explain why such a flow arriving from the northwest would have been mechanically easier than pulling mantle laterally (the slab was likely at that time a long and continuous structure) or from below (implying likely a crossing of the transition zone). Furthermore, this NW-SE asthenospheric channeled flow could also have been partially controlled by the neighboring Alpine and Pyrenean lithospheric roots. The absence of more recent tectonic or thermal events in the southern MC may explain why this asthenospheric flow could be preserved in the upper mantle. The beginning of the maximum intensity in the MC volcanism is roughly synchronous with the end of the Corsica rotation. This is perhaps not fortuitous; the southeastward asthenospheric flow beneath the southern MC may have deflected the ascending plume and, therefore, as the suction ended, the mantle plume

Fig. 6. Schematic upper mantle cross-section adapted from Séranne [39], trending NW-SE from the northern MC to the present-day Calabria location. See text for interpretation. The question mark at the base of the plume indicates the absence of argument for making this plume originate in the transition zone or arriving from the lower mantle. We propose that the upper mantle seismic anisotropy observed in the southern MC is located in the sublithospheric mantle and was generated by an asthenospheric mantle flow induced by the retreat and sinking of the Tethys slab beneath the Corsica-Sardinia block. may have freely continued its upward motion and generated the peak in the volcanic activity of the northern MC.

The present-day situation (Fig. 6d) shows the Tethys slab lying in the transition zone after more than $900 \mathrm{~km}$ of retreat, as imaged by seismic tomography $[41,42]$. The Calabria is separated from
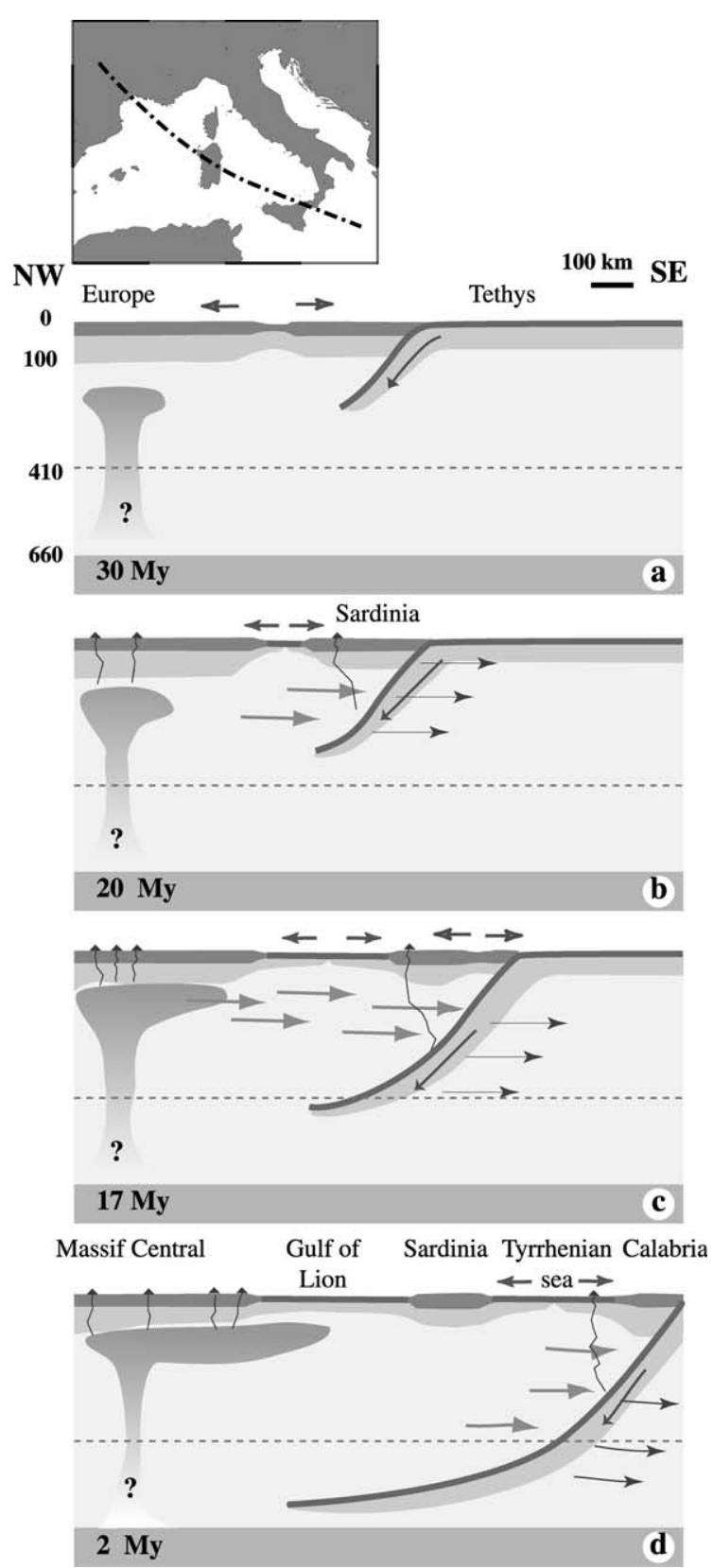
its original Corsica-Sardinia lithospheric block by the Tyrrhenian oceanic domain. The opening of this oceanic basin occurred after $10 \mathrm{Ma}$ and is related to a second episode of slab sinking. An asthenospheric mantle flow may have been induced by this event but could likely be of local extent since this sinking slab was narrow $[43,44]$ and no longer part of a laterally continuous structure. The mantle flow induced by the present-day slab roll-back likely has no direct influence on the asthenosphere beneath the southern MC. The southward migration of the MC volcanism occurring these last $2 \mathrm{Myr}$ could therefore reflect a passive plume spreading. The mantle deformation related to this final flow could superimpose on the previous one and could not be distinguished.

The lithospheric thickness is a key point in the discussion of the origin of the anisotropy beneath the southern MC. In the northern MC, the large negative Bouguer anomaly, the low seismic velocities observed by seismic tomography [9], and the high heat flows [7] all support a thin $(<60 \mathrm{~km})$ lithosphere. In the south, despite the lack of quantitative data on the lithospheric thickness beneath our network, the Tertiary extension may have affected the lithosphere around the Gulf of Lion, first mechanically during the rifting episode that began $30 \mathrm{Myr}$ ago and second, thermally during the slab roll-back episode and the asthenospheric flow related to the plume deflection. The base of the Hercynian lithosphere could have been thermally eroded during this Cenozoic episode. The $\mathrm{N}-\mathrm{S}$ elongated shape of the negative Bouguer anomaly is compatible with this hypothesis. The presence of two anisotropic layers, characterized by a lower asthenospheric layer and an upper Hercynian lithospheric layer cannot be ruled out but is not clearly demanded by our observations.

The thickness of the anisotropic layer that can explain our observed delay times depends on the intrinsic amplitude of anisotropy and therefore on the flow strength. Upper mantle nodules brought up at the surface by the volcanic activity provide a way to investigate their deformation fabrics, and therefore their seismic properties. The average $\mathrm{S}$-wave anisotropy deduced from more than a hundred upper mantle nodules from various geo- dynamic environments [19] is about 5.0\% around the $\mathrm{Z}$ structural direction (i.e., normal to the foliation plane, corresponding to the vertical direction in our case if we assume our hypothetic asthenospheric flow is dominated by horizontal foliations), requiring an anisotropic layer about $100 \mathrm{~km}$ thick to explain our $1.0 \mathrm{~s}$ delay times. This thickness can be considered as a lower bound, since these petrophysical measurements do not take into account variations in the structural orientation nor variations in the rock composition that can lower the overall seismic anisotropy. A regional analysis of upper mantle nodules [23] gives interesting insights. Seismic anisotropy calculated from olivine and orthopyroxene crystallographic preferred orientations on 10 peridotite nodules sampled in the $\mathrm{MC}$ volcanic rocks shows $\mathrm{S}$-wave anisotropies ranging between 1.4 and $5.3 \%$ [23]. Interestingly, low anisotropies $(<3 \%)$ are found in samples from the northern MC, extracted above the highest temperature anomalies [3] deduced from the seismic tomography [9]. This could suggest that the lithospheric fabric could have been partially erased by the temperature increase and perhaps by the fluid circulation related to the plume emplacement [37]. Such low anisotropy could explain the absence of splitting at some northern stations like CFF. On the periphery of this anomaly, and particularly in the southern MC, upper mantle nodules S-wave anisotropy is in the range 3-5\%, suggesting that the anisotropic layer could be 100 $150 \mathrm{~km}$ thick. The larger delay times observed at our southernmost stations are also compatible with a stronger flow related to the close vicinity of the sinking slab, and the smaller $\delta t$ at the northern stations could represent more diffuse mantle flow.

\section{Conclusions}

We have mapped upper mantle seismic anisotropy beneath the southern MC. Despite a rather small data set related to a short array deployment, we observe a consistent anisotropy pattern throughout this region, with contrasting characteristics compared to the neighboring Pyrenean 
pattern. Our observations suggest the presence of a NW-SE trending upper mantle flow in the central part of the network, i.e., between the north MC main volcanic area and the Mediterranean shore. The homogeneity of the results in this area does not favor a complex structure, such as, for instance, several anisotropic layers, but more a simple 'channel' structure. We propose that this channel could be the trace of a recent asthenospheric flow arriving from the NW and that could have filled the space left behind the sinking Tethys slab that induced the Corsica-Sardinia rotation between 22 and $17 \mathrm{Ma}$. We also propose that this asthenospheric flow could have deflected the plume ascending beneath the northern MC and could have thermally eroded the bottom of the lithosphere, erasing part of the Hercynian lithospheric preexisting fabric. The absence of subsequent tectonic and/or thermal event (except a possible recent passive plume spreading) may explain why such an asthenospheric structure may still be visible in the upper mantle. In such an interpretation, the slight $\phi$ rotation from NW-SE in the northern MC to almost E-W in SE France is not explained but could reveal an effect of the Alpine collision. The complex anisotropy signature in the southwestern part of our network may be explained by the presence of lateral anisotropy variations, since this area could represent the southwestern boundary of this channel.

\section{Acknowledgements}

This project is a contribution to the program 'Intérieur de la Terre' supported by the CNRS/ INSU. The 'Lithoscope' and 'Réseau Large Bande Mobile' programs provided seismic stations. Thanks to M. Kendall and D. Francis for the Leeds University broadband stations. We thank also the GFZ Potsdam for providing 10 mobile stations. Many thanks to all the people who helped in the field, particularly J. Dorel, U. Achauer, A. Vauchez, A. Tommasi, B. Ildefonse, P. Nicol, J. Bascou, and M. Duclos. We are grateful to P. Silver for his splitting analysis program. Constructive reviews provided by V. Babuska and S. Sobolev but also discussions with J.M. Dautria and M. Séranne were extremely helpful. Thanks to the Raynal, the Rimbaud and the Favier families for their welcome. We also thank the mayors of several villages for their help in providing site installations, in particular, at Mirandol, Alban, Courniou, Saissac, le Caylar, and Luc. We thank the 'Parc National des Cévennes' for their help at La Roche, and the French 'Ministère de la Culture' for allowing us to install stations on historical sites at Ensérune and Montmajour.[AC]

\section{References}

[1] O. Merle, L. Michon, The formation of the West European rift: a new model as exemplified by the Massif Central area, Bull. Soc. Géol. France 172 (2001) 81-89.

[2] G. Perrier, J.C. Ruegg, Structure profonde du Massif Central français, Ann. Geophys. 29 (1973) 435-502.

[3] S.V. Sobolev, H. Zeyen, M. Granet, U. Achauer, C. Bauer, F. Werling, R. Altherr, K. Fuchs, Upper mantle temperatures and lithosphere-asthenosphere system beneath the French Massif Central constrained by seismic, gravity, petrologic and thermal observations, Tectonophysics 275 (1997) 143-164.

[4] R.C. Maury, J. Varet, Le volcanisme tertiaire et quaternaire en France, in: A. Autran, J. Dercourt (Eds.), Géologie de la France - evolution géologique de la France, Mem. BRGM 107, 1980, pp. 139-159.

[5] R. Brousse, Le volcanisme en France, Rev. Ht.-Auvergne 44 (1974) 221-242.

[6] F. Lucazeau, R. Bayer, Evolution géothermique et géodynamique du Massif Central français depuis l'Oligocène, Ann. Geophys. 38 (1982) 405-429.

[7] F. Lucazeau, G. Vasseur, R. Bayer, Interpretation of heat flow data in the French Massif Central, Tectonophysics 103 (1984) 99-119.

[8] A. Souriau, M. Correig, M. Souriau, Attenuation of Rayleigh wave across the volcanic area of the Massif Central, France, Phys. Earth Planet. Inter. 23 (1980) 62-71.

[9] M. Granet, G. Stoll, J. Dorel, U. Achauer, G. Poupinet, K. Fuchs, Massif Central (France): new constraints on the geodynamical evolution from teleseismic tomography, Geophys. J. Int. 121 (1995) 33-48.

[10] S. Judenherc, M. Granet, N. Boumbar, Two-dimensional anisotropic tomography of lithosphere beneath France using regional arrival times, J. Geophys. Res. 104 (1999) 13201-13215.

[11] E. Larive, Modélisation du manteau supérieur sous le Massif Central français: inversion couplée des données de tomographie sismique et des anomalies de pesanteur, DEA, Université de Montpellier II, Montpellier, 1996.

[12] A. Nicolas, F. Lucazeau, R. Bayer, Peridotites xenoliths in Massif Central basalts: textural and geophysical evi- 
dence for asthenospheric diapirism, in: P.H. Nixon (Ed.), Mantle Xenoliths, John Wiley, New York, 1987, pp. 563574.

[13] M. Granet, M. Wilson, U. Achauer, Imaging a mantle plume beneath the French Massif Central, Earth Planet. Sci. Lett. 136 (1995) 281-296.

[14] A. Souriau, M. Granet, A tomographic study of the lithosphere beneath the Pyrenees, from local and teleseismic data, J. Geophys. Res. 100 (1995) 18117-18134.

[15] P.G. Silver, Seismic anisotropy beneath the continents: probing the depths of geology, Annu. Rev. Earth Planet. Sci. 24 (1996) 385-432.

[16] M.K. Savage, Seismic anisotropy and mantle deformation: what have we learned from shear wave splitting?, Rev. Geophys. 37 (1999) 65-106.

[17] D. Mainprice, G. Barruol, W. Ben Ismail, The seismic anisotropy of the Earth's mantle: from single crystal to polycrystal, in: S.I. Karato (Ed.), Earth's Deep Interior: Mineral Physics and Tomography from the Atomic to the Global Scale, Geodyn. Ser. 117, AGU, Washington, DC, 2000, pp. 237-264.

[18] A. Nicolas, N.I. Christensen, Formation of anisotropy in upper mantle peridotites: a review, in: K. Fuchs, C. Froidevaux (Eds.), Composition, Structure and Dynamics of the Lithosphere-Asthenosphere System, Geodyn. Ser. 16, AGU, Washington, DC, 1987, pp. 111-123.

[19] W. Ben Ismail, D. Mainprice, An olivine fabric database: an overview of upper mantle fabrics and seismic anisotropy, Tectonophysics 296 (1998) 145-157.

[20] B.L.N. Kennett, Seismic traveltime tables, in: T.J. Ahrens (Ed.), Global Earth Physics: A Handbook of Physical Constants, AGU Ref. Shelf. 1, AGU, Washington, DC, 1995, pp. 126-143.

[21] P.G. Silver, W.W. Chan, Shear wave splitting and subcontinental mantle deformation, J. Geophys. Res. 96 (1991) 16429-16454.

[22] G. Barruol, R. Hoffmann, Seismic anisotropy beneath the geoscope stations from SKS splitting, J. Geophys. Res. 104 (1999) 10757-10774.

[23] R. Hoffmann, Upper mantle seismic anisotropy in the vicinity of mantle plumes, Diplomarbeit, Universität Karlsruhe, Karlsruhe, Germany, 1998.

[24] P.G. Silver, M.K. Savage, The interpretation of shearwave splitting parameters in the presence of two anisotropic layers, Geophys. J. Int. 119 (1994) 949-963.

[25] V. Babuska, J. Plomerova, L. Vecsey, M. Granet, U. Achauer, Seismic anisotropy of the French Massif Central and predisposition of Cenozoic rifting and volcanism by Variscan suture hidden in the mantle lithosphere. Tectonics (2002) in press.

[26] G. Barruol, A. Souriau, A. Vauchez, J. Diaz, J. Gallart, J. Tubia, J. Cuevas, Lithospheric anisotropy beneath the Pyrenees from shear wave splitting, J. Geophys. Res. 103 (1998) 30039-30054.

[27] M. Granet, A. Glahn, U. Achauer, Anisotropic measurements in the Rhine graben area and the French Massif Central, Pure Appl. Geophys. 151 (1998) 333-364.
[28] G. Barruol, A. Souriau, Anisotropy beneath the Pyrenees range from teleseismic shear wave splitting, Geophys. Res. Lett. 22 (1995) 493-496.

[29] A.E. Gripp, R.G. Gordon, Current plate velocities relative to the hotspots incorporating the Nuvel-1 global plate motion model, Geophys. Res. Lett. 17 (1990) 1109-1112.

[30] P. Matte, Tectonics and plate tectonics model for the Variscan belt of Europe, Tectonophysics 126 (1986) 329-374.

[31] P.G. Silver, D. Mainprice, W. Ben Ismail, A. Tommasi, G. Barruol, Mantle structural geology from seismic anisotropy, in: Y. Fei, C. Bertka, B. Mysen (Eds.), Mantle Petrology: Field Observations and High Pressure Experimentation: A Tribute to Francis R. (Joe) Boyd, Geochem. Soc. Spec. Publ. 6 (1999) pp. 79-103.

[32] H.C. Nataf, Seismic imaging of mantle plumes, Annu. Rev. Earth Planet. Sci. 28 (2000) 391-417.

[33] R. Russo, E. Okal, Shear wave splitting and upper mantle deformation in French Polynesia: evidence for small-scale heterogeneity related to the society hotspot, J. Geophys. Res. 103 (1998) 15089-15107.

[34] I.T. Bjarnason, C.J. Wolfe, S.C. Solomon, G. Gudmundson, Initial results from the ICEMELT experiment: body wave delay times and shear-wave splitting across Iceland, Geophys. Res. Lett. 23 (1996) 459-462.

[35] K.T. Walker, G.H.R. Bokelmann, S.L. Klemperer, Shearwave splitting to test mantle deformation models around Hawaii, Geophys. Res. Lett. 28 (2001) 4319-4322.

[36] G. Rümpker, P.G. Silver, Calculating splitting parameters for plume-type anisotropic structures of the upper mantle, Geophys. J. Int. 143 (2000) 507-520.

[37] X. Lenoir, C.J. Garrido, J.L. Bodinier, J.M. Dautria, Contrasting lithospheric mantle domains beneath the Massif Central (France) revealed by geochemistry of peridotite xenoliths, Earth Planet. Sci. Lett. 181 (2000) 359375.

[38] L. Michon, O. Merle, The evolution of the Massif Central rift: spatio-temporal distribution of the volcanism, Bull. Soc. Géol. France 172 (2001) 69-80.

[39] M. Séranne, The Gulf of Lion continental margin (NW Mediterranean) revisited by IBS: an overview, in: B. Durand, L. Jolivet, F. Horvath, M. Séranne (Eds.), The Mediterranean Basins: Tertiary Extension within the Alpine Orogen, Geological Society, London, 1999, pp. 1536.

[40] C. Faccenna, F. Funiciello, D. Giardini, P. Lucente, Episodic back-arc extension during restricted mantle convection in the Central Mediterranean, Earth Planet. Sci. Lett. 187 (2001) 105-116.

[41] G.B. Cimini, P-wave deep velocity structure of the southern Tyrrhenian subduction zone from nonlinear teleseismic traveltime tomography, Geophys. Res. Lett. 26 (1999) 3709-3712.

[42] F.P. Lucente, C. Chiarabba, G.B. Cimini, D. Giardini, Tomographic constraints of the geodynamics evolution of the Italian region, J. Geophys. Res. 104 (1999) 20307-20327. 
[43] E. Carminati, M.J.R. Wortel, W. Spakman, R. Sabadini, The role of slab detachment processes in the opening of the western-central Mediterranean basins: some geological and geophysical evidence, Earth Planet. Sci. Lett. 160 (1998) 651-665.
[44] Z. Gvirtzman, A. Nur, Residual topography, lithospheric structure and sunken slabs in the central Mediterranean, Earth Planet. Sci. Lett. 187 (2001) 117-130. 